\title{
Energy performance of a dual airflow window under different climates
}

\author{
Jingshu Wei ${ }^{1}$, Jianing Zhao ${ }^{1}$, Qingyan Chen ${ }^{1,2, *}$ \\ ${ }^{1}$ School of Municipal and Environmental Engineering, Harbin Institute of Technology, \\ Harbin, Heilongjiang Province, China \\ ${ }^{2}$ School of Mechanical Engineering, Purdue University, West Lafayette, Indiana, USA \\ *Corresponding email: yanchen@purdue.edu
}

\begin{abstract}
Ventilated windows have shown great po tential in conserving energy in buildings and provide fresh air to improve indoor air qua lity. This paper reports our effort to use EnergyPlus to simulate the energy performance of a dual airflow window under different climate. Our investigation first develope $\mathrm{d}$ a network $\mathrm{m}$ odel to accoun $\mathrm{t}$ for th e twodimensional heat transfer in the window sy stem and i mplemented it in EnergyPlus. The two-dimensional assumption and the modified EnergyPlus program were validated by the measured temperatures of the window and th e energy dem and of a test cell with the window under actual weather conditions. Then EnergyPlus was applied to analyze energy performance of a s mall apartm ent installe $d$ with the dual airflow windows in fi ve different climate zones in China. The energy used by the apartment with blinds wind ows and low-e windows was also calculated for com parison. The dual airflow window can reduce heating energy of the apartment, especi ally in cold clim ate. The cooling energy reduction by the window was less im portant th an that by shading solar radiation. The dual airflow window is recomm ended for colder clim ate. If improving air quality is a major consideration for a building, the window can be used in any climate.
\end{abstract}

Keywords: Dual airflow window; Energy demand; Indoor air quality; Different climates

\section{Introduction}

Energy dem and by buildings in China acco unts for nearly $30 \%$ o f the total primary energy and HVAC syste ms use $55 \%$ of the energy for buildings [1]. In order to reduce energy dem and by the HVAC system $\mathrm{s}$, it is essential to re duce energy loss in winter and energy gain in summ er through bui lding envelopes, such as windows, walls, roofs, and floors, and through infiltration. The heat loss through windows and infiltration in residential buildings accounts for roughly 50\% in Northern China. As a result, glazing has been increased from single to double, even triple layers. A parallel effort has been made to improve the frame and glazing properties. For example, it is becoming more and more common to use low e missivity (low-e) coatings to reduce radiation and to seal window leakage. 


\begin{tabular}{|c|c|}
\hline \multicolumn{2}{|c|}{ Nomenclature } \\
\hline$C_{p}$ & specific heat capacity $(\mathrm{J} /(\mathrm{kg}, \mathrm{K}))$ \\
\hline$Q_{\text {solar1 }}$ & solar heat gain rate (W) \\
\hline$Q_{\text {cond }}$ & condutive heat exchange rate (W) \\
\hline $\mathrm{Q}_{\text {conv }}$ & convective heat exchange rate (W) \\
\hline $\mathrm{Q}_{\mathrm{r}}$ & radiative heat exchange rate between surfaces (W) \\
\hline$Q_{\text {sup,in }}$ & energy brought in by supply airflow (W) \\
\hline$Q_{\text {sup,out }}$ & energy carried away by supply airflow (W) \\
\hline$Q_{\text {exh,in }}$ & energy brought in by exhaust airflow (W) \\
\hline $\mathrm{Q}_{\text {exh,out }}$ & energy carried away by exhaust airflow (W) \\
\hline $\mathrm{T}$ & absolute temperature $(\mathrm{K})$ \\
\hline $\mathrm{h}$ & convective heat transfer coefficient $\left(\mathrm{W} /\left(\mathrm{m}^{2}, \mathrm{~K}\right)\right)$ \\
\hline 1 & conductive heat transfer coefficient $\left(\mathrm{W} /\left(\mathrm{m}^{2}, \mathrm{~K}\right)\right)$ \\
\hline$\varepsilon$ & infrared emissivity for each glass layer \\
\hline$\rho$ & air density $\left(\mathrm{kg} / \mathrm{m}^{3}\right)$ \\
\hline \multicolumn{2}{|c|}{ Subscripts } \\
\hline e & exhaust airflow \\
\hline in & indoor space \\
\hline j & layer j of the dual-airflow window \\
\hline out & outdoor space \\
\hline s & supply airflow \\
\hline 1 & outer surface of outer glass pane \\
\hline 2 & inner surface of outer glass pane \\
\hline 3 & outer surface of middle glass pane \\
\hline 4 & inner surface of middle glass pane \\
\hline 5 & outer surface of inner glass pane \\
\hline 6 & inner surface of inner glass pane \\
\hline
\end{tabular}

Better window and wall construction have made buildings increasingly tighter, which is good for energy conservation. However, the effort $m$ ay be at the expense of adequate indoor air quality (IAQ) [ 2]. Th e Environm ental Protection Agency in the United States (http://www.epa.gov/iaq/ia-intro.html) reported that, inadequate ventilation can increase indoor pollutant levels. Poor indoor air quality has been linked to respiratory illness, aller gies, asthm a, and sick building syn drome [3]. Therefore, how to conser ve energy and to maintain acceptable indoor air quality has been challenging.

One way to i mprove indoor air quality is to supply fresh air through window frame. By supply directly very cold air in wi nter and very warm air in summer to a room through the window frame can waste a lot of energy and cause discomfort. Heat recovery ventilator or enthalpy recove ry ventilator are popular used in commercial and industrial 
buildings. It can transfer heat between the exhaust air and the supply fresh air is thus used to conserve energy [4,5]. Such heat recovery system is often integrated with central airconditioning system $\mathrm{s}$ [5], so it is not suitab le for residential build ings with hydraulic heating system s and window/split air-condit ioning units. S ome buildings used double skin facade to trap solar energy and to suppl y fresh air into indoor space [6]. However, it is too expensive to be used in residential buildings [7].

Airflow windows work like a double skin facade, which can be used in residential buildings [8] and some of them can work like a heat exchanger [9]. The past studies show that the airflow windows have very prom ising performance on energy conservation and indoor air quality improvement. Our effort is to study one of the best airflow windows by analyzing its energy performance under different climates, by comparing with the energy performance of other popular windows. This study $\mathrm{m}$ ay provide guide under which climate such an airflow window should be used.

\section{Principle of airflow windows}

The main difference between an airflow window and a conventional window is the existence of free or forced flow convection in the cavity between two layers of glass. Depending on the airflow pattern and window structure, Fig. 1 shows five $m$ odes of operation for airflow windows [9]: supply, exhaust, indoor air curtain, outdoor air curtain, and dual airflow window. Note that the outside is on the left side of each window and the inside on the right side.

The supply m ode (Fig. 1(a)) draws fres h outside air through the cavity into building. The air is heated in the cavity by solar radiation so the mode is for winter heating. The exhaust air mode (Fig. 1(b)) extr acts inside air through cavity to the outside space. The window uses cool indoo $\mathrm{r}$ air and bu oyancy force from the solar radiatio $\mathrm{n}$ to cool the window panels and to remove heat accumulated in the cavity. The exhaust mode is for summ er passive cooling. The indoor air curtain window (Fig. 1(c)) uses solar radiation to heat indoor air in winter. The outdoor air curtain window (Fig. 1(d)) circulates the outdoor air by solar radiation to cool the windo w panels in summer. There is no air exchange between indoor and outdoor through the air curtain windows. Venetian blinds are often added into the cavity to enha nce the flow because so lar radiation can be easily trapped by the blinds. The dual airflow window (Fig. 1(e)) has two airflow paths in which the outer airflow path supplies fresh out door air to the inside space and the inner airflow path extracts ind oor air to th e outside space. The m id-glazing w orks like a heat exchanger. The first four m odes can be ope rated by buoyancy force from solar radiation or mechanical force by a fan. The dual airflow window must operate with two fans.

Compared to a conventional window, all the airflow windows can capture solar heat trapped in the cavity and directed it indoors or outdoors depe nding on the operating mode. This reclaimed solar energy is used as passive heating in winter or passive cooling in summ er. The dual airflow window is be tter than the supply and exhaust mode windows because the former has a higher effici ency due to the heat exchanger function . The window is also better than the outside and inside curtain ones because it can bring in fresh air to inside [10]. 


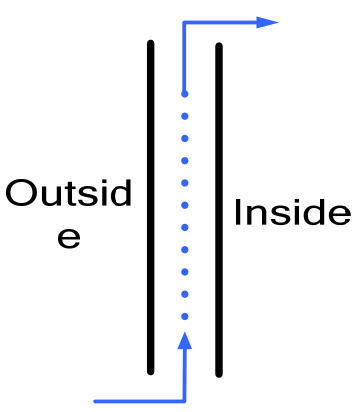

(a)

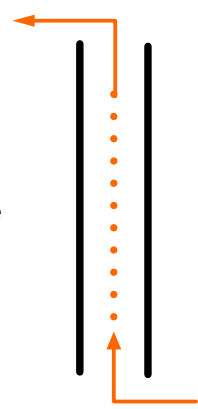

(b)

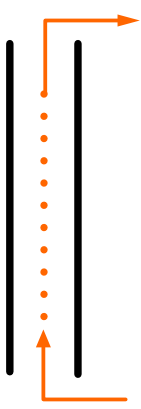

(c)

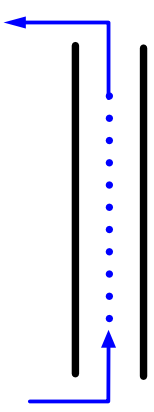

(d)

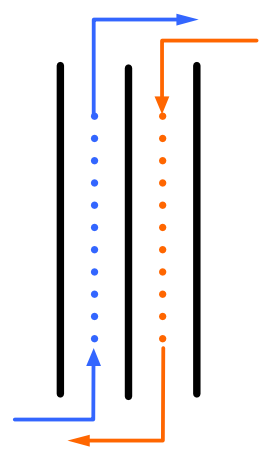

(e)

Fig.1. Operating modes of airflow windows: (a) supply mode, (b) exhaust mode, (c) indoor air curtain mode, (d) outdoor air curtain mode, and (e) dual airflow mode

The dual airflow window can conserve en ergy and can improve indoor air quality by supplying fresh outdoor air to indoor spaces. Go sselin and Chen [10] dem onstrated in laboratory environm ent that the dual airf low window can conserve energy. However, their study was with steady-state heat transfer and did not com pare with the performance of other windows. This investigation is to further evaluate the energy performance of the dual-air window for different climate in China and to compare the performance with that of other conventional windows.

\section{Methods}

In order to evaluate the energy perf ormance, this investigation compared the dual airflow window with a double-pane, low-e window and a double-pane, blinds window, as shown in Fig. 2. The low-e and blinds wind ows were selected because they were probably the best windows currently used in Chinese residential buildings.
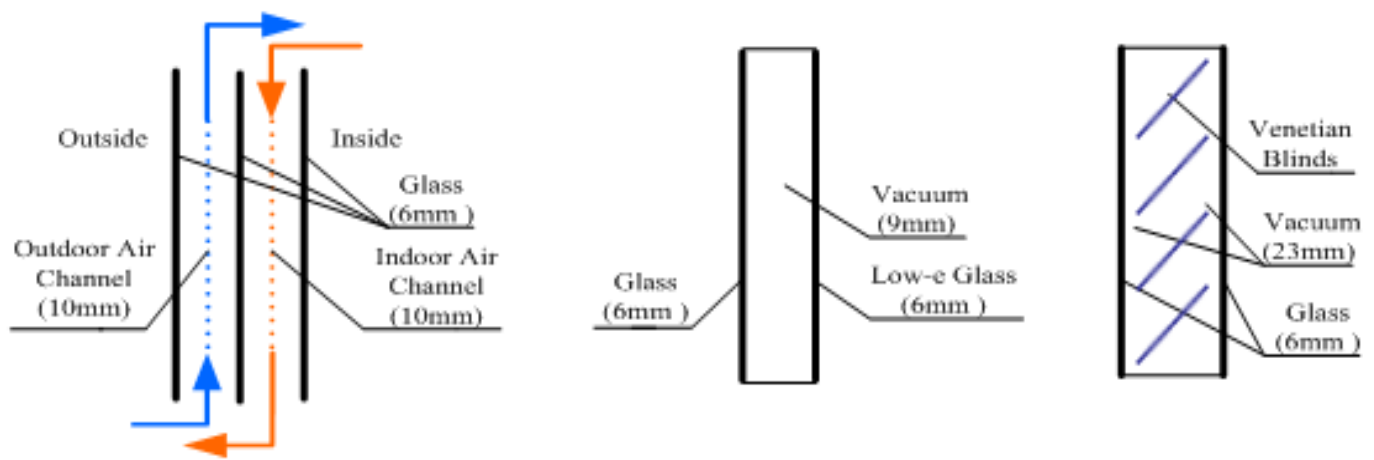

Fig. 2. Three different windows used in this study (a) dual airflow window, (b) low-e window, and (c) blinds window 
The dual airflow window was constructed with three clear glasses with no coating. The thickness of airflow cha nnel between two glasses $\mathrm{w}$ as $10 \mathrm{~mm}$ as suggested by Gosselin and Chen [9]. The thickn ess of the glasses was $6 \mathrm{~mm}$ that provides sufficient strength. The sam e was used for the other tw o windows. Both the low-e and blinds windows were double-pane since th ey are traditional type in China and they can satisfy the insulation requirem ents by the Chinese national standards. The low-e window was with a low em issivity coating on interior surface of the in ner gl ass. T he coating can reduce the long-wave radiation loss to the outside space [11]. The cavity between the two glazing layers was $9 \mathrm{~m} \mathrm{~m}$. The blinds window had venetian blinds in the cavity between the two glas $s$ panes that can m ainly absorb solar radiation in winter and reflect a major part of solar radiation back to the outside in summer. In the winter night, the blinds work as an insulation layer that can red uce heat lo ss to the ou tside space [12]. The cavity thickness was $23 \mathrm{~mm}$ that perm itted the $\mathrm{m}$ ovement of the $20 \mathrm{~mm}$ width of blind $\mathrm{s}$ in between. This study assum ed the blinds were closed in sum mer daytime and in winter nighttime.

With the three types of windows, one $m$ ay use different methods to analyze their energy perfor mance, such as the bin- methods, experim ental $\mathrm{m}$ easurements, Computational Fluid D ynamics (CFD), and energy analysis program s. The bin-m ethods are too simple for the comparison of the energy performance of these windows since they do not consider solar radiation and approximate the energy demand as a linear function of outdoor air tem perature. Thus, the $\mathrm{m}$ ethods are not suitable fo $\mathrm{r}$ our investigation, although they are simple and straightforward. The approach of experim ental measurements is most reliable and realistic. However, the approach is very expensive and time consuming. It would be unrealistic to us e the approach for studying energy dem and in different clim ate regions for a period of one year. The CFD m ethod can give accurate and informative results by solving highly reliable Navier-Stokes equations. Unfortunately, the method would demand a large computer for the simulation of energy demand for one year under various weather conditions. The a pproach by using energy analysis program $\mathrm{s}$ such as EnergyPlus [13] a nd ESP-r [14] si mulates energy perform ance by s olving onedimensional energy equation [ 15]. It is ve ry fast f or calculating energy dem and over a long period of time. Therefore, the approach was used for the present investigation. Since EnergyPlus was validated by $m$ any researchers and its source code was relatively simple to modify, it was used in this study.

EnergyPlus calculates heat and mass transfer through building enclosure, such as windows, walls, roofs, etc. The program solves different layers of a window as different nodes. It also assum es the temperature along the entire window height to be uniform as shown in the three-pane window in Fig. 3( a). The three-pane window has six nodes and six temperatures.

Due to the flow through the two caviti es in the dual airflow window, the temperature of a glass pane in the vert ical direction cannot be uniform . The air temperatures in the cavities also change along the height. Therefore, this study cannot use directly EnergyPlus without $\mathrm{m}$ odifications for the vertical change of tem perature. The modifications were to divide the window into $\mathrm{n}$ equal sections along the height as shown in Fig. 3(b). 


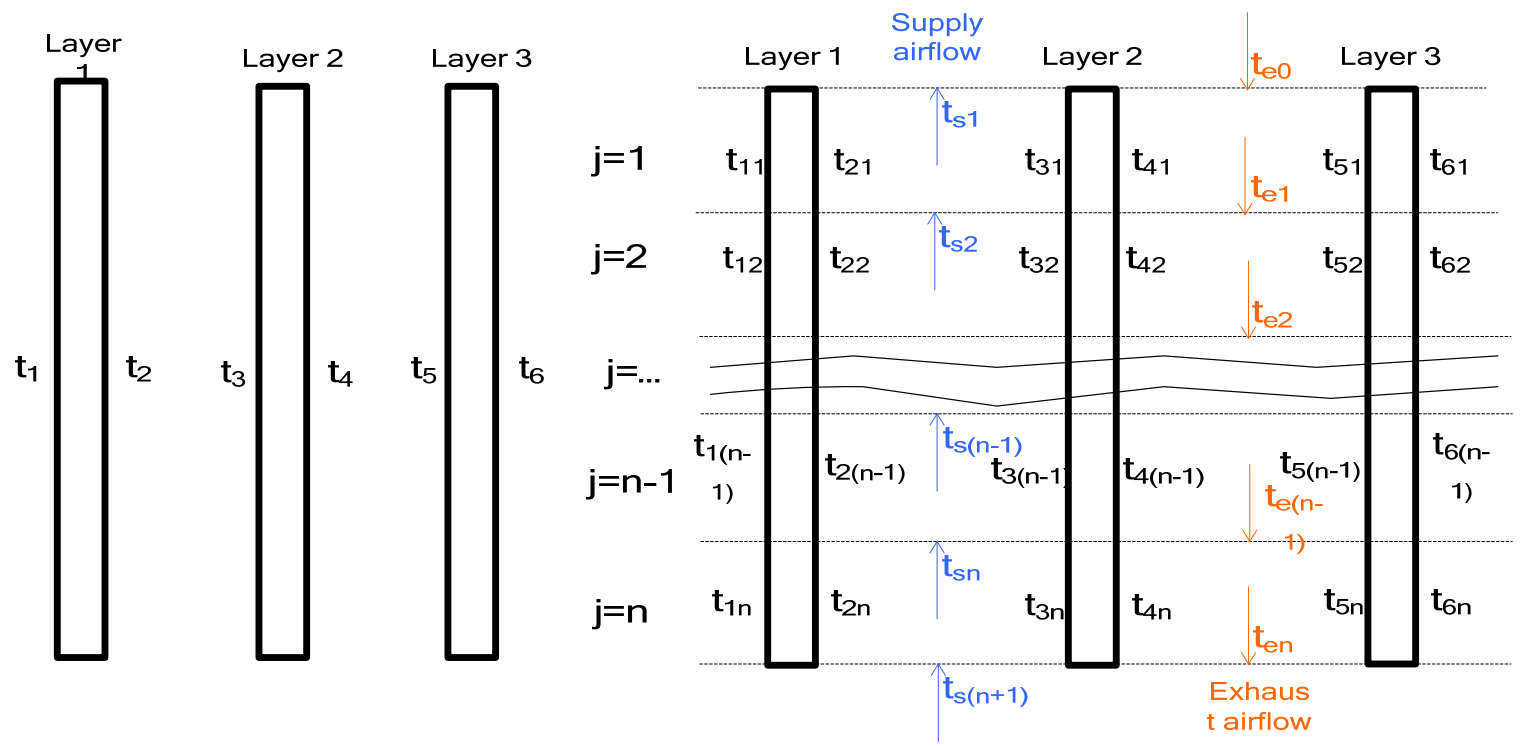

(a) A conventional three-pane window

(b) A dual airflow window

Fig. 3. Schematic of window network models for EnergyPlus

\subsection{Implementation of the network model into EnergyPlus}

More specifically, our modi fications were implemented by a new network m odel. The model was based on the energy balance for each section, which considers convection, conduction, and solar radiation through the glass panes, and radiation exchange between the glass panes and the interior and exterior spaces as shown in Fig. 4(a). For the section, the existing equations in EnergyPlus can be used. The energy and $m$ ass balance between sections were only considered in the two cavities. The heat transfer along the glass height was neglected. This investigation also did not consider the heat and $\mathrm{m}$ ass transfer in the third direction. Thus, this study had i mplemented two additional flow e quations for the cavities. Fig. 4(b) shows further the param eters used in this study. Please refer to the nomenclature for the explanation of the parameters. Please note th at $\mathrm{m}$ ost of th $\mathrm{e}$ parameters were variables.

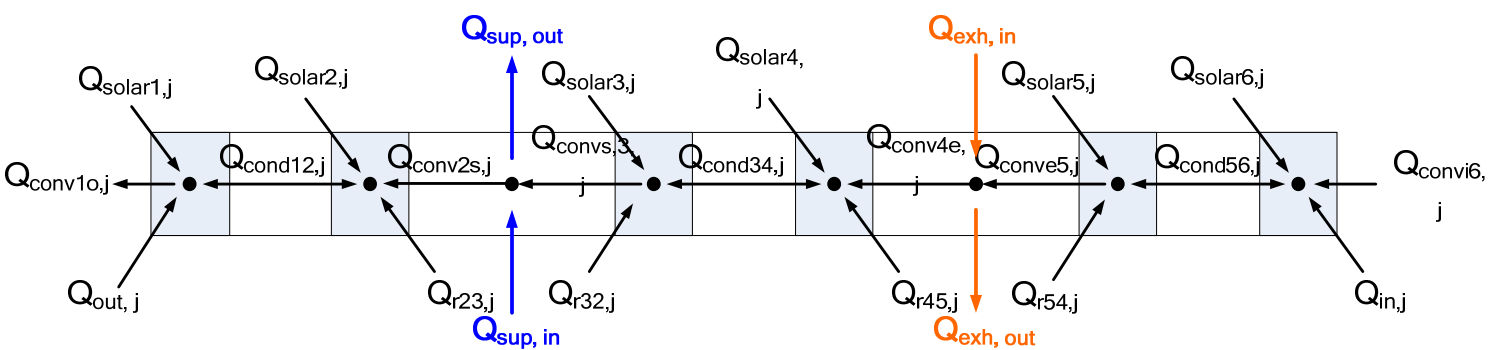

(a) Energy balance in a section 


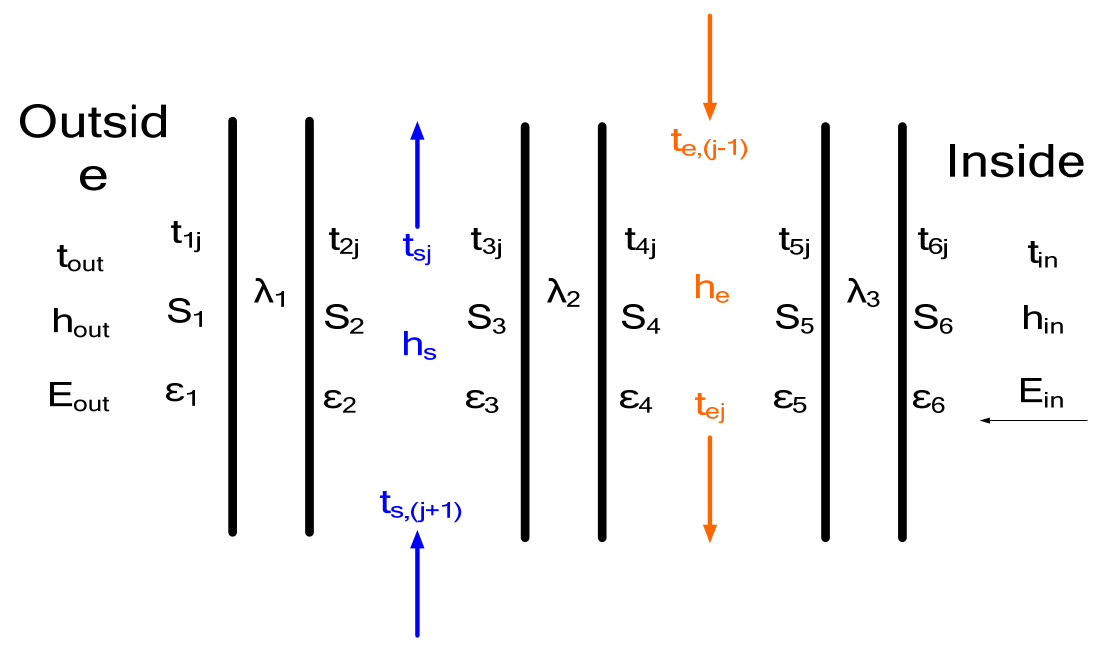

(b) Parameters used for the section

Fig. 4. Schematic of heat and mass flow through section $\mathrm{j}$ of the dual airflow window

Fig. 4(a) shows that the dual airflow wi ndow has eight nodes in a section. For node 1 , the energy balance equation is

$$
E_{\text {out }} \varepsilon_{1}-\varepsilon_{1} \sigma T_{1 j}^{4}+\lambda_{1}\left(T_{2 j}-T_{1 j}\right)+h_{\text {out }}\left(T_{1 j}-T_{\text {out }}\right)+Q_{\text {solar } 1}=0
$$

Similarly, the equation for node 2 can be written as

$$
\lambda_{1}\left(T_{1 j}-T_{2 j}\right)+h_{s}\left(T_{s j}-T_{2 j}\right)+\sigma \frac{\varepsilon_{2} \varepsilon_{3}}{1-\left(1-\varepsilon_{2}\right)\left(1-\varepsilon_{3}\right)}\left(T_{3 j}{ }^{4}-T_{2 j}{ }^{4}\right)+Q_{\text {solar } 2}=0
$$

For the air layer in the outer cavity (node 3), one can establish its energy balance equation to be

$$
h_{s}\left(T_{s j}-T_{2 j}\right)+h_{s}\left(T_{s j}-T_{3 j}\right)+\rho V_{s} c_{p}\left(T_{s j}-T_{s,(j+1)}\right)=0
$$

For the mid-pane, the energy equations for nodes 4 and 5 are similar. They are

$$
\begin{aligned}
& h_{s}\left(T_{3 j}-T_{s j}\right)+\lambda_{2}\left(T_{4 j}-T_{3 j}\right)+\sigma \frac{\varepsilon_{2} \varepsilon_{3}}{1-\left(1-\varepsilon_{2}\right)\left(1-\varepsilon_{3}\right)}\left(T_{2 j}{ }^{4}-T_{3 j}{ }^{4}\right)+Q_{\text {solar } 3}=0 \\
& \lambda_{2}\left(T_{3 j}-T_{4 j}\right)+h_{e}\left(T_{e j}-T_{4 j}\right)+\sigma \frac{\varepsilon_{4} \varepsilon_{5}}{1-\left(1-\varepsilon_{4}\right)\left(1-\varepsilon_{5}\right)}\left(T_{5 j}{ }^{4}-T_{4 j}{ }^{4}\right)+Q_{\text {solar } 4}=0
\end{aligned}
$$

Easily, one can find the energy balance equations for the inner cavity (node 6) to be: 


$$
h_{e}\left(T_{5 j}-T_{e j}\right)+\lambda_{3}\left(T_{6 j}-T_{5 j}\right)+\sigma \frac{\varepsilon_{4} \varepsilon_{5}}{1-\left(1-\varepsilon_{4}\right)\left(1-\varepsilon_{5}\right)}\left(T_{4 j}{ }^{4}-T_{5 j}{ }^{4}\right)+Q_{\text {solar } 5}=0
$$

Finally, we can es tablish the e nergy balance equations for th e inner glass-pane (nodes 7 and 8) to be:

$$
\begin{aligned}
& h_{e}\left(T_{e j}-T_{4 j}\right)+h_{e}\left(T_{e j}-T_{5 j}\right)+\rho V_{e} c_{p}\left(T_{e j}-T_{e,(j-1)}\right)=0 \\
& E_{i n} \varepsilon_{6}-\varepsilon_{6} \sigma_{6 j}{ }^{4}+\lambda\left(T_{5 j}-T_{6 j}\right)+h_{i n}\left(T_{i n}-T_{6 j}\right)+Q_{\text {solar } 6}=0
\end{aligned}
$$

The eight equations are for the eight unknown temperatures. But, many of the parameters shown in Fig. 4(b) are tem perature dependent and the air temperatures along the cavity height are related. Thus, iteration between sections and among the eight equations is needed to obtain a converged solution.

\subsection{Experiment setup for obtaining data to validate EnergyPlus}

Since the network m odel use assum ptions, it is essential to validate the modified EnergyPlus program by experimental data. The validation is to estimate the impact of two dimensional assumptions for the three-di mensional window on the energy dem and and temperature distributions. Go sselin and Chen [9] conducted experimental measurements of the dual airflow window without solar ra diation. Should the data be used, the validation would be incom plete. Therefore, this investigation conducted experim ental measurements of airflow and heat transfer through the win dow in a room under actual weather conditions, which was with solar ra diation, convection, and conduction. Since such experim ent was for th e program validation, it is unnecessary to conduct the experiment for a long period of time. The data for one or two days would be suffi cient. Then the validated program could be used to com pare the energy perf ormance of the three windows in different climates.

This investigation used the heat box $\mathrm{f}$ acilities at th e Harbin Institu te of Technology in China to obtain reliable expe rimental data to validate the $\mathrm{m}$ odified EnergyPlus program. The $f$ acilities $w$ ere on the roof of a $f$ our-storey building an $d$ no taller buildings were in the nea rby area that eliminated the potential effect of the nearby buildings on the wind conditions around the faci lities. This study used six test cells from the facilities: three of them south-facing and the other three north-facing, as shown in Fig. 5. The three south- and thre e north-facing cells had the dua 1 airflow window, the low-e window, and the blinds window, respectively. The walls with the windows were the only exterior ones, and the rest were interior ones that were co ntrolled to be adiabatic. The control was achieved by exposin $\mathrm{g}$ all the interior walls, $\mathrm{r}$ oofs, and floors in a large interior air-conditioned space th at had the sam e air temperature as that of the six cells. Fig. 4 shows the dimension of the cells an $d$ the windows. The exterior walls were constructed with $490 \mathrm{~m}$ m brick and $100 \mathrm{~mm}$ be nzene board for insu lation. The airf low rate through the dual airflow window was $40 \mathrm{~m}^{3} / \mathrm{h}$, and drawn by fans installed in the window. 


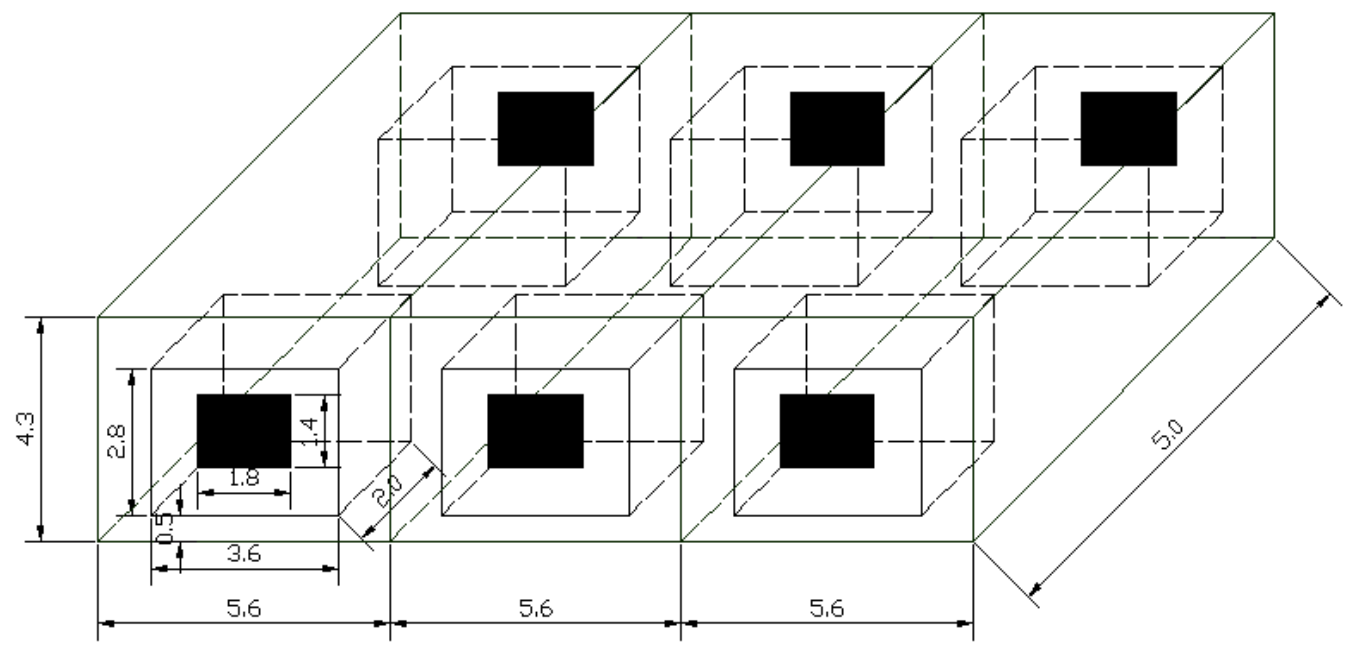

Fig. 5. Sketch of the facilities with six cells installed with the windows (black area) (m)

Each cell used an air conditioner in coo ling season and an electric heater in heating season to control the cell air temperature. The indoor air te mperature in each cell was measured by $\mathrm{HOBO}$ tem perature senso rs and data loggers. The energy dem and by the air conditioners and heaters was also m easured. A series of ther mocouples were used to measure glass pane tem peratures and air temperatures in the window system $\mathrm{s}$. This investigation installed a HOBO Micro Weather Station to collect local weather data at the facilities, s uch as outdo or air tem perature, dew point temperat ure, wind speed, wind direction, solar radiation, and relative humidity. The data was used in EnergyPlus as input weather data. This paper used the weather data during the one week experiment and only the glass pane tem peratures and energy dem and data of the last day of the experim ent to validate the modified EnergyPlus program. It is im portant to use one week weather data to eliminate the impact of large thermal inertial of the facilities on the energy demand and temperatures calculated.

From the schem atic of the window structure shown in Fig. 6, the flow in the window system should be three-dim ensional. As the modified EnergyPlus program simplified the heat and mass transfer in the dual airflow window to be two dimensional, it is essential to study their im pact on temperature along the third di mension by comparing the calculated tem perature $\mathrm{w}$ ith the data $\mathrm{m}$ easured with the 16 thermocouples on the surface of both the inner and outer glass panes. 

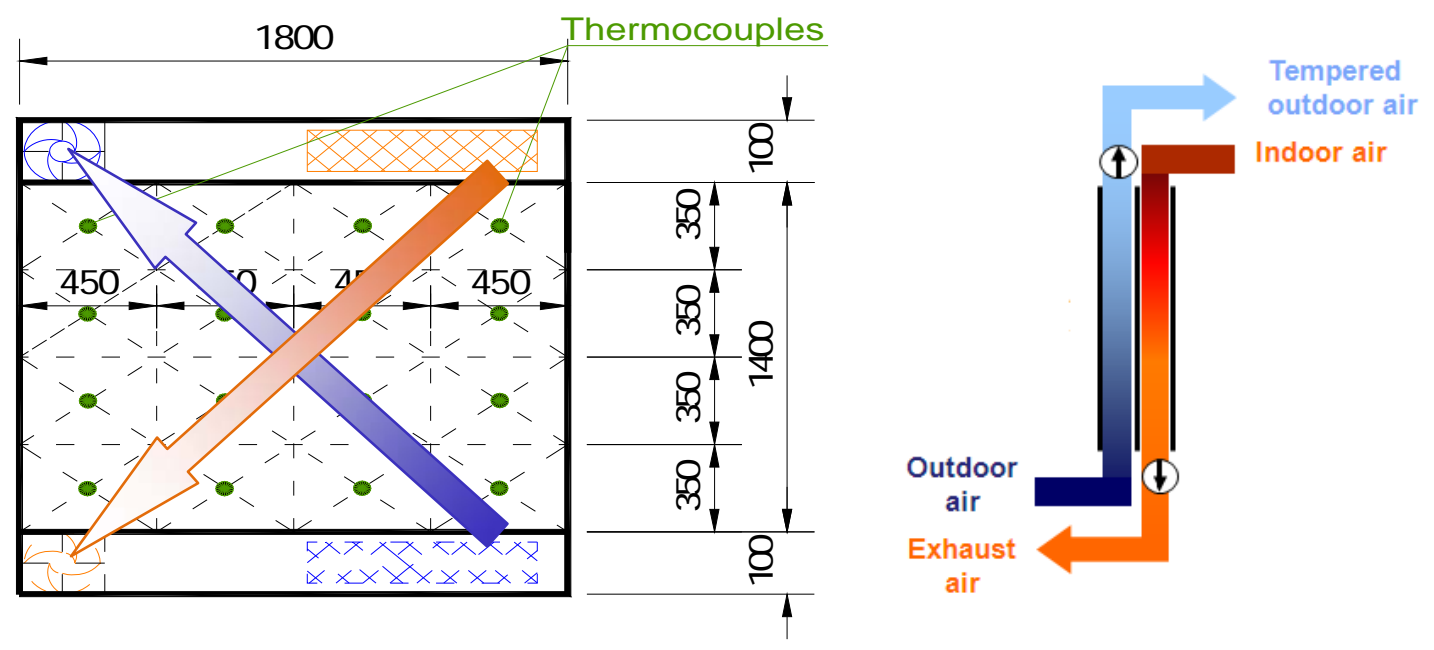

Fig. 6. Locations of the thermocouples and inlet and outlet of the two flow streams on the dual airflow window

\section{Results}

\subsection{Validation of the modified EnergyPlus program}

The experim ent for va lidating the assum ption used in th e third $\mathrm{d}$ imension $\mathrm{w}$ as conducted on a sunny day in Harbin, August 2, 2007. Table 1 show s the tem perature distributions at $12: 00 \mathrm{pm}$ on that day. The data shows that the tem perature difference on the vertical direction ranged from 2.2 to $9.4 \mathrm{~K}$ and that on the horiz ontal direction 0.1 to $1.4 \mathrm{~K}$. The tem perature difference between the outdoor and indoor air was $44.8 \mathrm{~K}$. Clearly, the tem perature differe nce along the horizontal direc tion (the third dim ension) was much smaller than that in the o ther two directions. Therefore, the two-dim ensional approximations used in EnergyPlus seem reasonable.

\section{Table 1}

Temperature distributions on the glass panes of the dual airflow window at 12:00 noon on August 2, 2007

(a) Inner glass pane

\begin{tabular}{|l|l|l|}
\hline 23.3623 .03 & 21.54 & 22.93 \\
\hline 23.1922 .78 & 22.66 & 23.24 \\
\hline 25.8524 .56 & 24.25 & 27.09 \\
\hline 26.0625 .21 & 26.80 & 27.45 \\
\hline
\end{tabular}

(b) Outer glass pane

\begin{tabular}{|l|l|l|}
\hline 25.3526 .39 & 26.79 & 26.60 \\
\hline 27.9628 .07 & 27.72 & 27.56 \\
\hline 35.0333 .04 & 32.51 & 33.18 \\
\hline 33.7833 .48 & 33.92 & 34.20 \\
\hline
\end{tabular}

The validation of the network $\mathrm{m}$ odel used in the $\mathrm{m}$ odified EnergyPlus program used the energy dem and $m$ easured from the e xperimental facilities. The weather data used was measured from February 17 to 23,2007 when it was sunny. This period was 
almost the coldest days in Harbin in 2007. The validation is to compare the com puted energy demand with the corresponding measured data for the cells installed with the three types of windows for Fe bruary 23, 2007. Fig. 7 shows that the simulated energy demand profiles of the cells ag ree well with the measured data with a difference mostly less than $0.01 \mathrm{~kW}$. The difference between the m easured and computed results is equivalent to the energy loss due to $0.9 \mathrm{~m}^{3} / \mathrm{h}(0.045 \mathrm{ACH})$ infiltration under a temperature difference of 40 $\mathrm{K}$ between the indoor and outdoor air. One can im agine that the uncertainties in predicting infiltration could be larger than $0.045 \mathrm{ACH}$. The difference is accep table. The simulated $\mathrm{c}$ urves a re $\mathrm{s}$ moother th an the $\mathrm{m}$ easured ones, which is another possible evidence of the fluctuated infiltration.

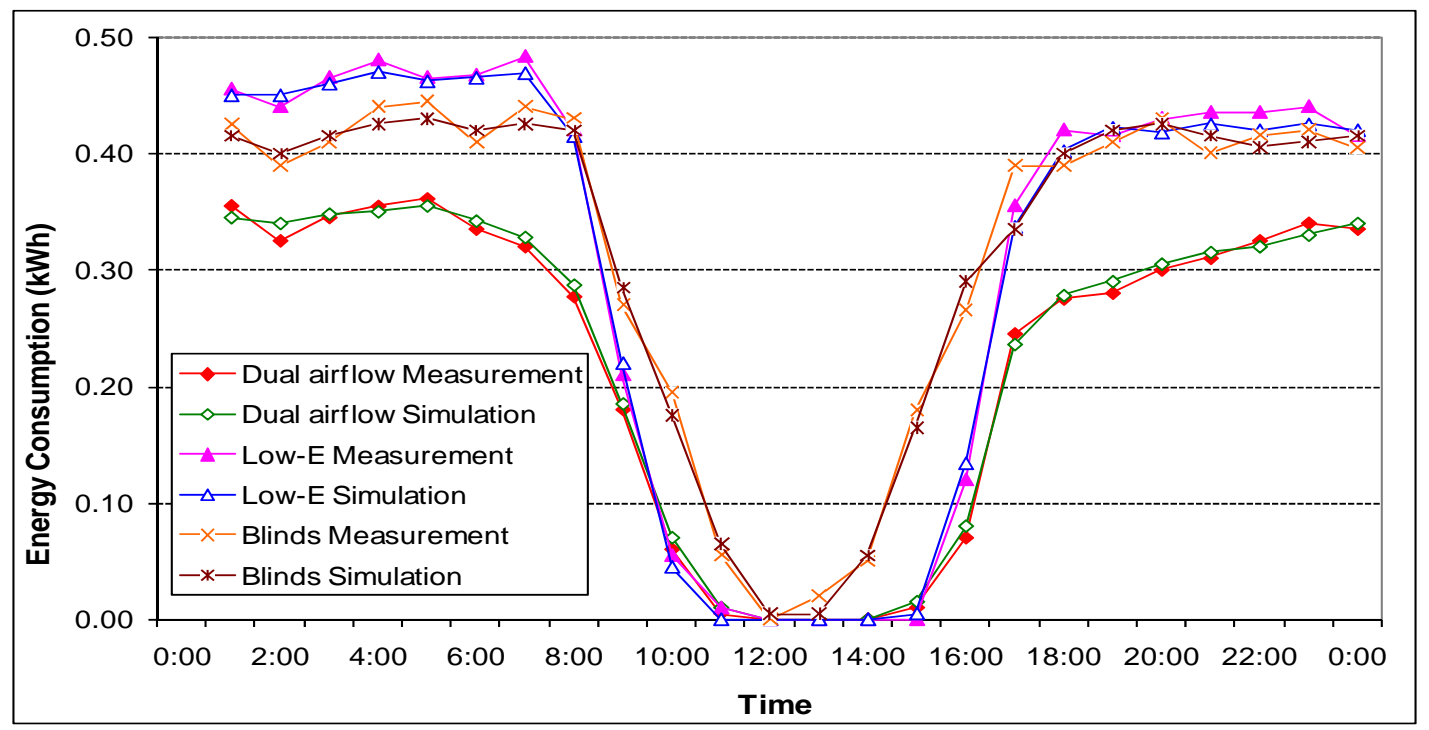

(a) Windows without ventilation in the south-facing cells

(b)

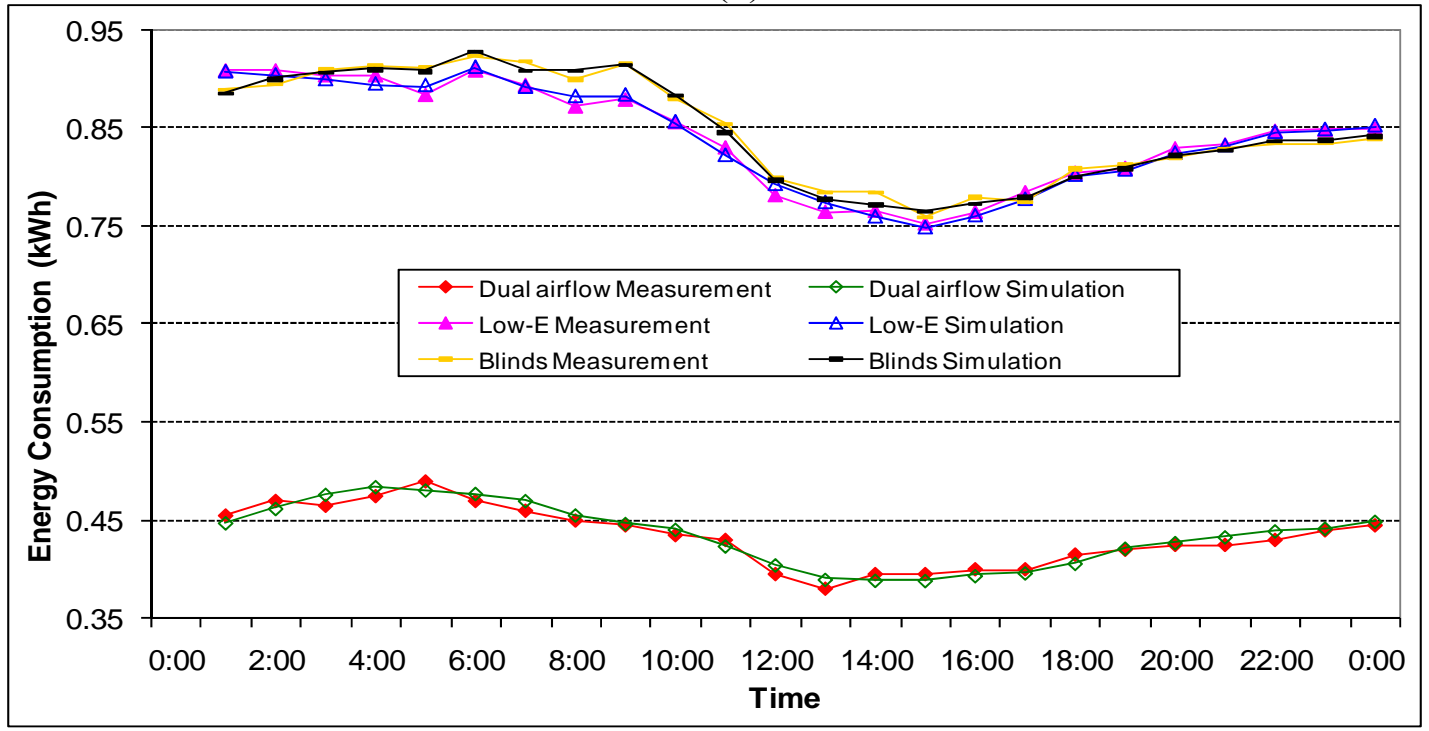

(b) Windows with ventilation in the north-facing cells 


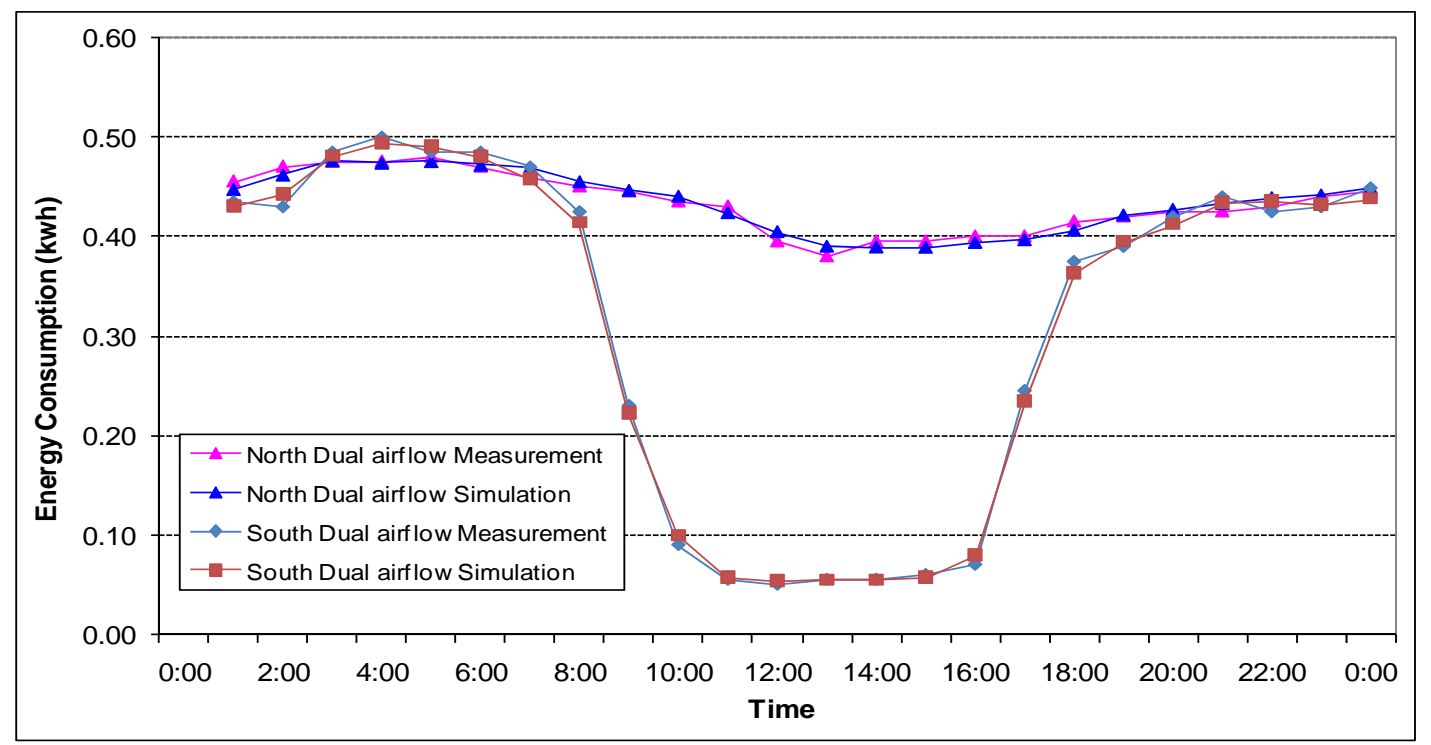

(c) Dual airflow window with ventilation in both north-facing and south-facing cells

Fig. 7. Comparison of computed energy demand by the cells with the three types of windows with the experimental data of February 23, 2007

Fig. 7(a) shows the energy demand of the three south-facing cells without window ventilation. The cell with the dual airflow window demanded the least energy becau se it had the best insulation due to the three gla ss-panes construction. The energy dem and for all the cells with the three types of window became smaller from 9:00, reached to zero in the noon time, and then turned larger again in the afternoon. The change should be due to the heat gain from sola $r$ radiation. The cell with the blinds window dem anded more energy than that with the low-e and dual airflow windows between 9:00 and 17:00 since the reflection of blinds decreased the heat gain from the so lar radiation. The validation shows the modified EnergyPlus can sim ulate correctly the dual ai rflow window without ventilation.

Fig. 7(b) shows the energy dem and for the three cells with north-facing windows and $40 \mathrm{~m}^{3} / \mathrm{h}$ supply air rate. The low-e and blinds window were assum ed to be a ble to supply outdoor air directly to the cells via a supply fan. The measured data was modified to factor the impact of the ventilation on en ergy demand. The figure depicts that the cell with the dual airflow window required only about a half of the energy compared with that for the cells with the other two windows. The significant reduction on energy dem and in this case is due to heat recovery between the two streams of flows in the window cavities in the dual airflow window. The e nergy demand for all the cells with the three types of window changed little during the day due to littl e solar radiation from the north and very large temperature differential between indoor and outdoor air. The validation concludes that the m odified EnergyPlus can s imulate correctly the heat exchang e between su pply airflow and exhaust airflow in the dual airflow window.

Fig. 7(c) depicts the dif ference of ener gy demand between the cell with the dual airflow window facing south and that facing no rth. In the night, the difference was sm all since the radiation was similar. In the day time, the cell with the south facing window required much less en ergy than tha $\mathrm{t} w$ ith the north facing one. Clear ly, solar $\mathrm{r}$ adiation 
played a very im portant role here. The $\mathrm{m}$ odified EnergyPlus program can also sim ulate accurately the solar radiation.

These efforts have demonstrated that th e m odified EnergyPlus can be used to calculate energy demand for a room with the dual airflow window.

\subsection{Analysis of annual energy demand for an apartment with the dual airflow window using the modified EnergyPlus program}

The validated EnergyPlus program was then used to sim ulate energy dem and for an apartment with the three di fferent types of window for fi ve climate zones in China. This investigation chos e one repres entative city from each clim ate zone. The cities are Harbin (sev ere c old), Beijing (co ld), Shangha i (ho $t$ in su mmer and cold in win ter), Guangzhou (hot in summer and mild in winter), and Kunming (mild). Table 2 and Figure 8 present the detailed climate information of the five cities.

Table 2

Location and design day climate conditions in the five different cities

\begin{tabular}{|c|c|c|c|c|c|}
\hline & \multicolumn{3}{|c|}{ Location } & \multicolumn{2}{c|}{ Summer/Winter design day } \\
\hline City name & Longitude & Latitude & $\begin{array}{c}\text { Elevation } \\
(\mathrm{m})\end{array}$ & $\begin{array}{c}\text { Maximum/Minimum } \\
\text { dry bulb temperature } \\
\left({ }^{\circ} \mathrm{C}\right)\end{array}$ & $\begin{array}{c}\text { Daily } \\
\text { temperature } \\
\text { range }\left({ }^{\circ} \mathrm{C}\right)\end{array}$ \\
\hline Harbin N45.72 & E126.68 & 126.62 & $30.3 /-29$ & 8.3 \\
\hline Beijing N39.79 & E116.46 & 31.1 & $33.2 /-12$ & 8.8 \\
\hline Shanghai N31.16 & E121.43 & 4.6 & $34 /-4$ & 6.9 \\
\hline Guangzhou N23.04 & E116.67 & 6.7 & $33.5 / 5$ & 6.5 \\
\hline Kunming & $\mathrm{N} 25.02$ & E102.68 & 1891.3 & $25.8 / 1$ & 6.9 \\
\hline
\end{tabular}

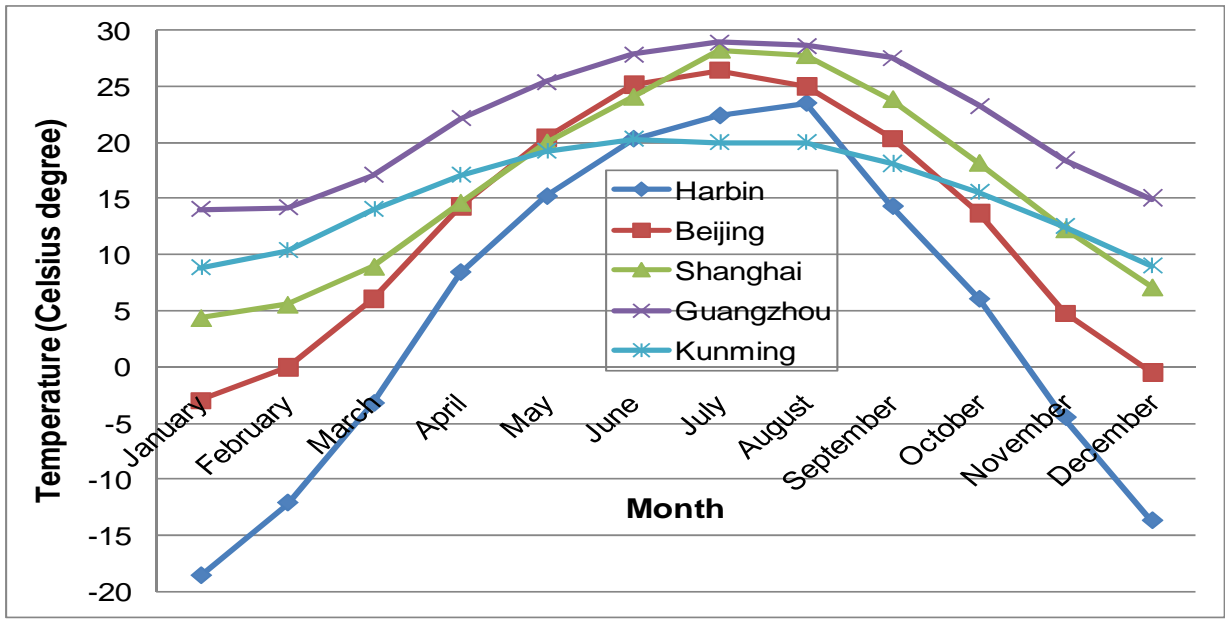

(a) Monthly average outdoor dry bulb temperature $\left({ }^{\circ} \mathrm{C}\right)$ 


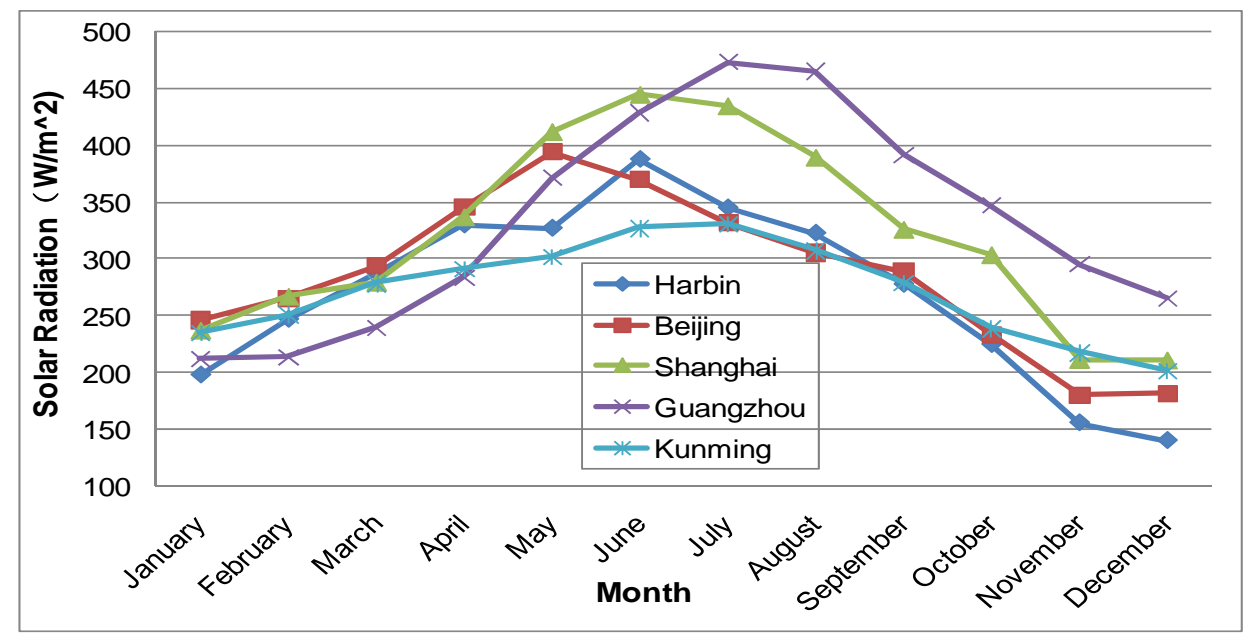

(b) Monthly average solar radiation

Fig. 8. Climate conditions in the five different cities

Fig. 9 shows the layout of a generic apartment with a $60 \mathrm{~m}^{2}$ floor area. It was on a middle floor of an apartm ent building and ne ighbored with other ap artments. Therefore, only the south and north walls that were $\mathrm{w}$ ith the windows were the exterior ones. The rest walls, roof, floor were interior envelope. Since its neighboring rooms were assumed to have the same air temperature, the interior walls could be consider ed as adiabatic. The balcony was enclosed so the window between the kitchen and the balcony was an interior window. The balcony space was treated as a room without heati ng or cooling. The exterior walls were constructed $\mathrm{w}$ ith $360 \mathrm{~mm}$ brick and $80 \mathrm{~mm}$ benzene board of insulation. In the figure, $\mathrm{W}-1$ and $\mathrm{W}-2$ were two different sizes of windows, which can be the dual airflow window, low-e window, or blinds window. When W-1 and W-2 were the dual airflow windows, only the fixed panels $(800 \mathrm{~mm}$ wide) were th ree layers and the operable parts were conventional double-pane.

This inv estigation assu med that th ere $w$ ere tw o persons in the apa rtment. The airflow rate through each of the $\mathrm{W}-1$ window and the $\mathrm{W}-2$ window wa s $24 \mathrm{~m}^{3} / \mathrm{h}$. This made a total of $72 \mathrm{~m}^{3} / \mathrm{h}$ of fresh outside air enteri ng the apartm ent through the three windows. The flow rate $\mathrm{m}$ et the AS HRAE Standard of $10 \mathrm{~L} / \mathrm{s}$ per person for providing acceptable indoor air q uality in the apartm ent. The fan power consumption for all the three windows was estimated to be $50 \mathrm{~W}$. Our simulations considered two scenarios: one with the $72 \mathrm{~m}^{3} / \mathrm{h}$ ventilation all the time and the othe $\mathrm{r}$ no v entilation at all. This study further assumed that the total electric load was $100 \mathrm{~W}$ from lighting and equipm ents. The indoor air tem perature was allowed to swing between 20 and $26 \quad{ }^{\circ} \mathrm{C}$. W ithin this temperature range, no heating or cooling was needed.

Due to the lim ited space available, this paper presented detailed results only for Harbin with the seve re cold winter clim ate and Gua ngzhou with the hot summ er mild winter climate. For other cities, only the summary results were presented. 


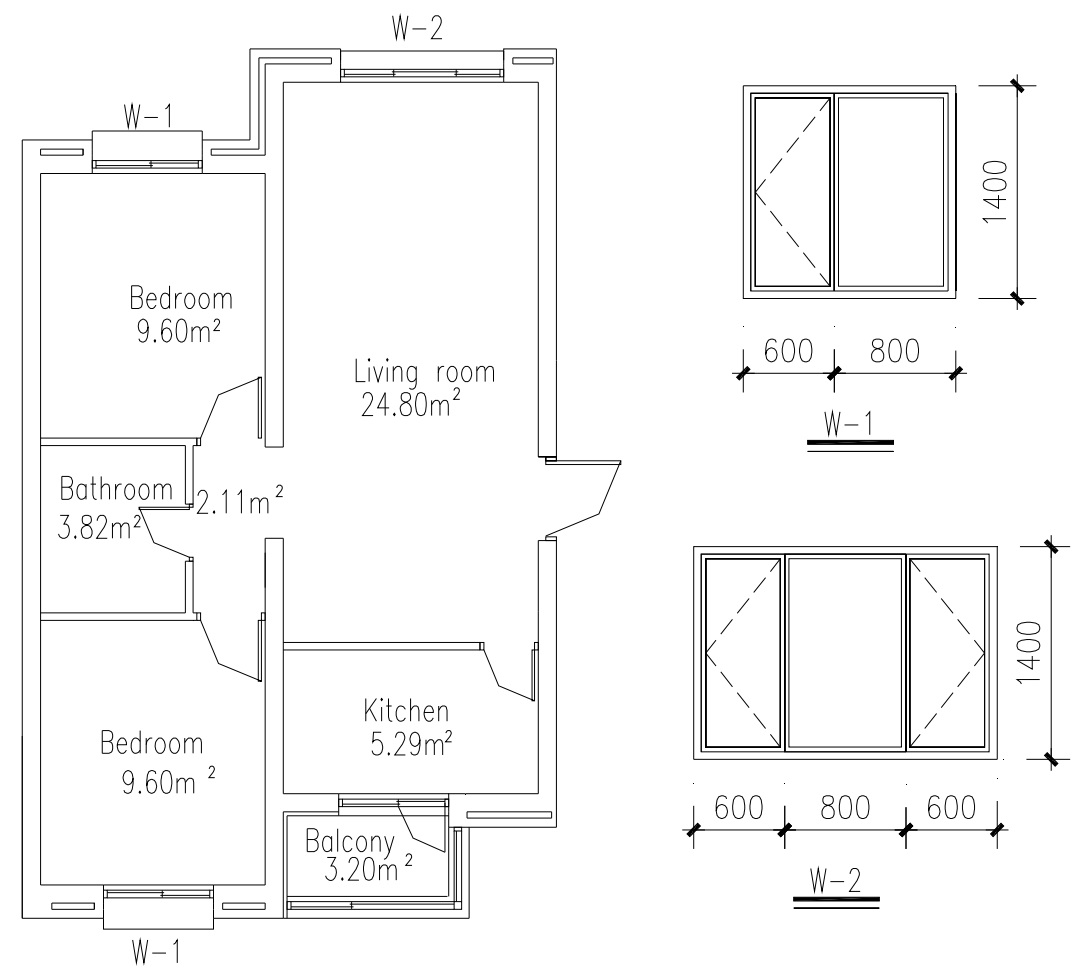

Fig. 9. Layout of the house installed with the windows (W-1 and W-2)

Fig. 10 shows the $m$ onthly energy dem and for Harbin with and without window ventilation. The figure shows that heating was required for the apartment from October to May and cooling from April to September.

Without window ventilation, the case with dual airflow windows de manded the least heating energy and that with the blinds windows re quired the most. Clearly, the insulation of the dual airflow windows was the highest and that of the blinds windows the lowest. The dual airflow windows benefited from the three-layer glazing construction. The low-e window had a better insulation th an the blinds window due to the low emissivity coating on the inner pane, which can decrease infrared radiation heat loss from the inner space to outer space. The difference in heating demand is small among the three types of windows. In the cooling season, th e case with the low-e windows needed most cooling energy and the one with the bli nds w indows the least. The cooling energy demanded by the case with the dual airflow wi ndows was slightly less than that with the low-e windows. This is because the low-e windows and the dual airflow windows allowed the solar to be transmitted into the apartment due to no shading device, while the blinds windows can reflect solar back to the outdoor space. The solar reflection decreased the solar heat gain and cooling dem and. Figure 8(a) shows Harbin has a cool summ er, even in the hottes $\mathrm{t}$ month, the av erage tem perature is lower than $26{ }^{\circ} \mathrm{C}$. Thus, the total cooling energy demand was small. 


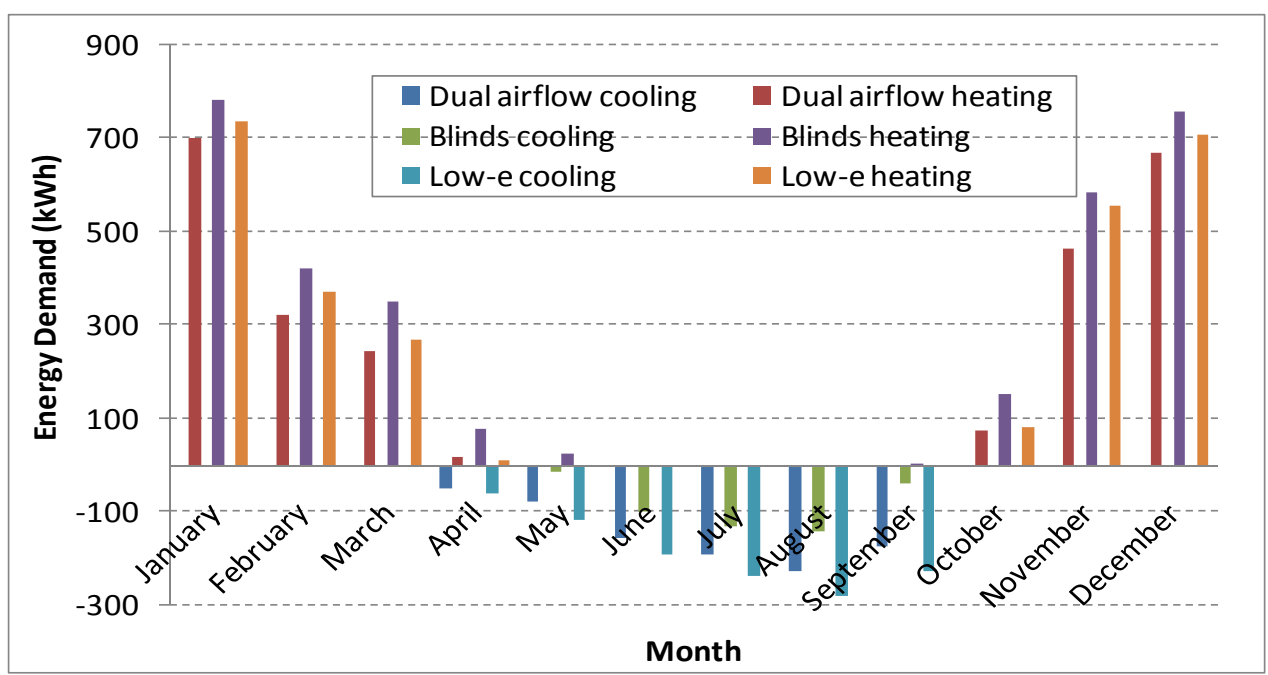

(a) Without window ventilation

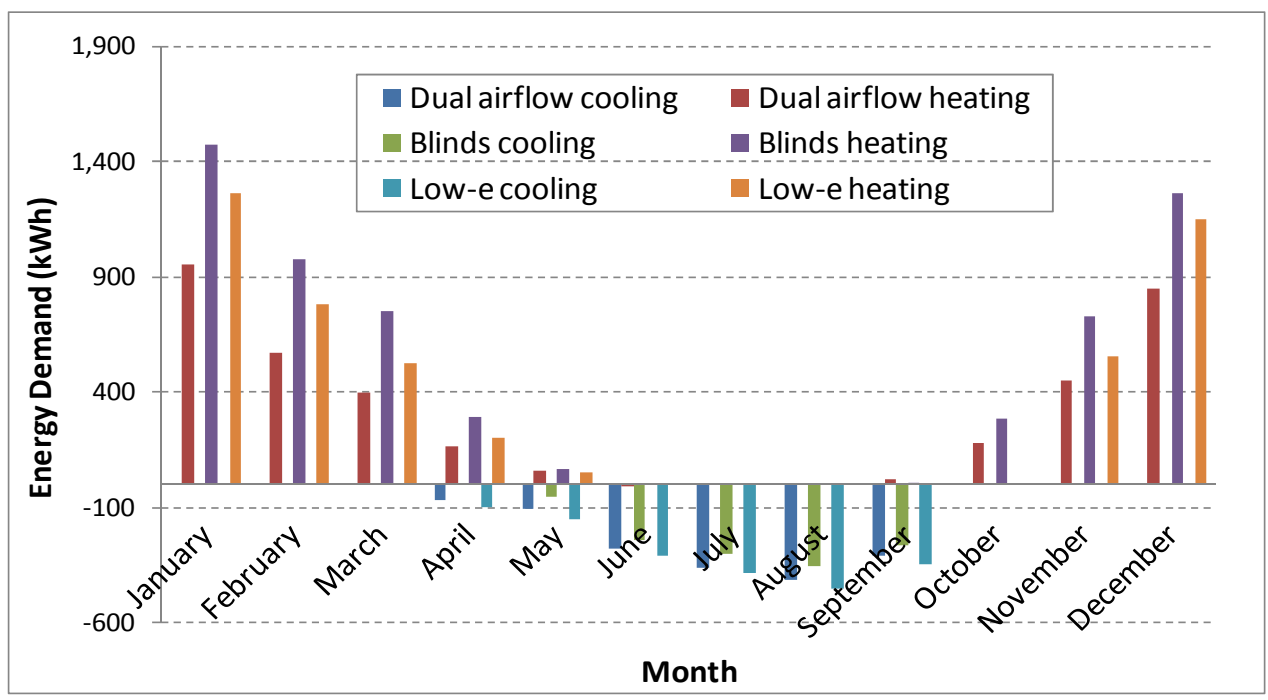

(b) With window ventilation

Fig. 10. Monthly energy demand for the apartment with the three types of windows in Harbin (severe cold climate)

With window ventilation, Fig. 10(b) depicts that the heat ing load increased for all the cases because the outdoor air temperature was low in Harbin. In the coldest $\mathrm{m}$ onth, the average tem perature difference between indoor and outdoor was almost $40 \mathrm{~K}$. Thus the heating load is very high. The increase was especially evident for the cases with low-e and blinds windows because they did not have any heat recovery capability. Compared to the apartment with the sam e windows without ventilation, the increased energy dem and for the apartment was $87 \%$ and $63 \%$ for the low-e and blinds windows, respectively. The heating energy demand of the case with the dual airflow windows was also increased but only by a moderate rate of $39 \%$, due to the heat recovery by the windows. Overall, the apartment with dual airflow windows dem anded 36\% lower energy th an that with the low-e windows and $48 \%$ lower energy than that with the blinds windows in the heating 
season. On the other hand, the cooling load of the apartment with the window ventilation decreased a little in the cooling period, compared to that without the window ventilation. This is because, even in the hottest month (July) in Harb in, the air tem perature in the night was lower than that indoors. This can be seen from Figure 8(a), in July and August, the average monthly temperature is less than $26^{\circ} \mathrm{C}$, while the daily $\mathrm{h}$ igh temperature can be higher than $26^{\circ} \mathrm{C}$ in most days. The vent ilation in the night can effectively cool down the building structure (especially the exterior wall with heavy thermal mass) that reduced the cooling dem and. The dual airflow window can make the air tem perature in the outer cavity higher that can further reduce the heat transfer to the room through the window. The heat recovery from the dual airflow windows was low since the air tem perature difference between the tw o cavities $w$ as small. From energy dem and point of view, the dual airflow window should be recomm ended in the heating season not in the cooling season in Harbin. However, the main drive to use the dual airflow window is to im prove indoor air quality by bring outdoor air to indoor.

Fig. 11 shows the m onthly energy demand for the apartm ent with the th ree types of windows in Guangzhou (hot summ er and mild winter clim ate). The results show that heating was needed only from November to March but cooling from April to November. This corresponds to Fig. 8. Only when the averaged monthly temperature is lower than $20^{\circ} \mathrm{C}$, the apartm ent with these win dows needs heating. By contras $\mathrm{t}$, when the averaged monthly temperature becomes higher and with solar radiation, it needs cooling.

Fig. 11(a) illustrates th e heating and cooling dem and for the cases without ventilation. The tren $d$ is similar to that $f$ or Harbin so the ex planation for Harbin can be applied here as well. Fig. 11(b) shows the energy demand for the apartment with window ventilation. In the heating season, the cas e with the dual airflow windows dem anded the least energy and that with blinds windows de manded the most, which is in consistence with that found in Harbin. The winter was mild in Guangzhou so the energy dem and for heating was small. In the cooling season, the case with the blinds windows de manded the lowest energy, since only the blinds window can reflect solar heat gain back to the outdoor space in the daytim e. The case with the low-e wi ndows demanded the highest energy. This is b ecause the dual airflow wi ndows can cool d own the ho t supply airflow and can reduce the heat transfer from the out door air to the window as explained for the case in Harbin. Compared to the cases without wi ndow ventilation, the cases w ith window ventilation increased the energy dem and by $19 \%$ for the dual airflow windows, $21 \%$ for the blinds windows, and $26 \%$ for th e low-e windows, respectively. $\mathrm{T}$ his is because in the cooling season the ventilation by the warm outdoor air would significantly increase the cooling demand. In addition, the heat recovery capacity of the case with the dual airflow windows was low because the te mperature difference between the two air streams in the window was sm all. Overall, the case with the dual airflow windows ventilation required $27 \% \mathrm{~m}$ ore cooling energy than that with the blinds windows. Thus, shading was more important than heat recovery in summer in Guanzhou. 


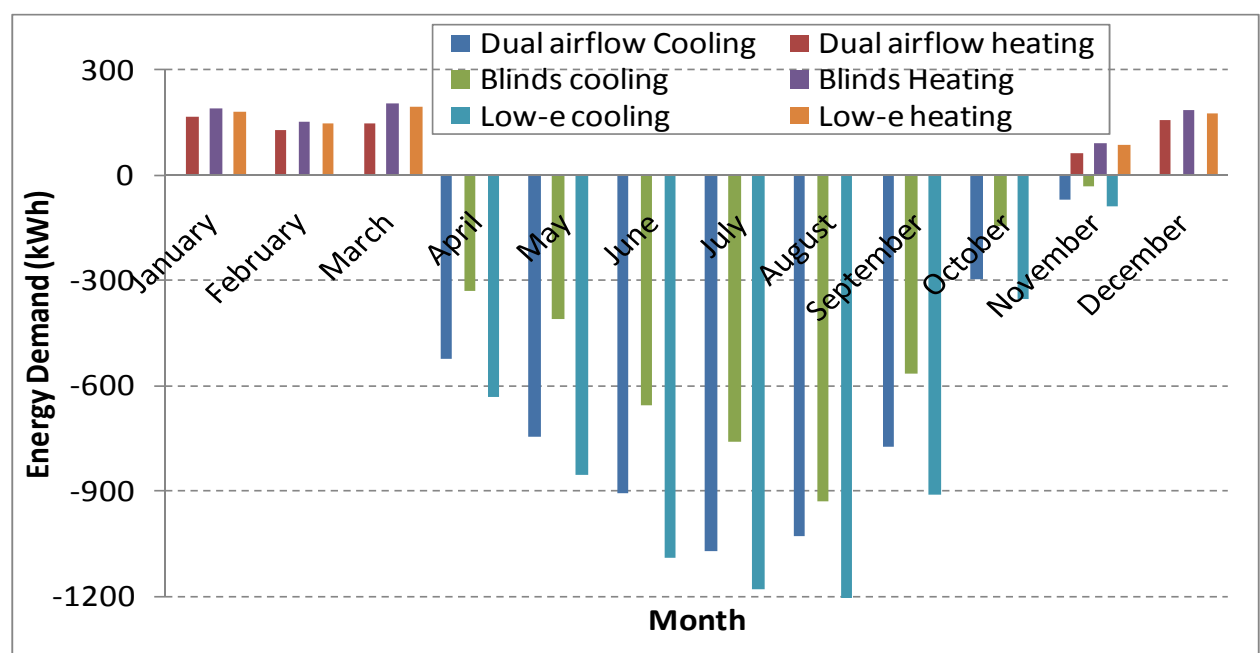

(a) Without window ventilation

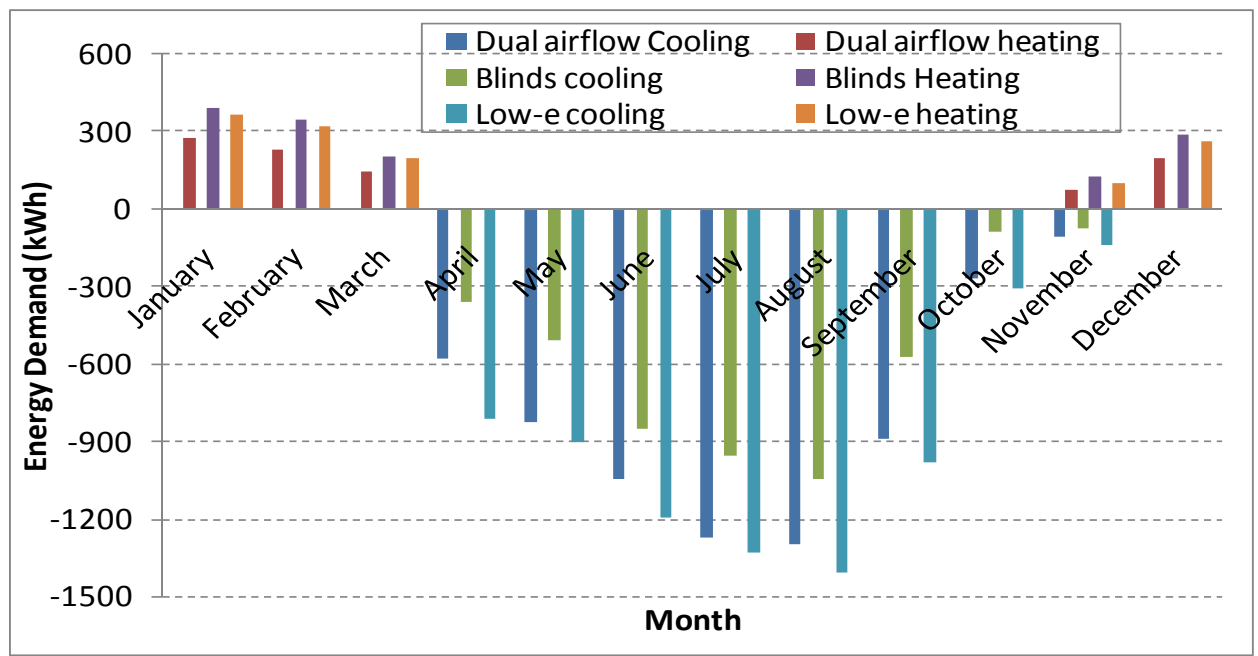

(b) With window ventilation

Fig. 11. Monthly energy demand for the apartment with the three types of windows in Guangzhou (hot summer and mild winter climate)

Table $3 \mathrm{~g}$ ives a sum marized com parison of the total energy dem and of the apartment in the five climate zones studied. The table compares the energy demand of the apartment with the dual airflow windows to th at with the blinds and low-e windows. The analysis for Harbin and Guangzhou can be used for other clim ate zones. In the heating season, the case with the dual airflow windows us ed the lowest energy, and that with the blinds windows used the highest. $\mathrm{T}$ he heat recovery of the dual airflow window can effectively reduce the energy dem and. Th e annual energy dem and shows that the efficiency of the dual airflow win dows in conserving energy beco mes higher as the climate gets colder. In the cooling s eason, the case with the blinds windows required the least energy, but that with th e low-e windows needed the most. Thus it is im portant to shade the $w$ indows. If the dual airflow window can be shaded from solar radiation, the cooling energy demand could be reduced to be smaller than that with the blinds window. The energy recovery by the dual airflow wi ndow in summ er was not very effective. 
However, the dual airflow window can bring outdoor fresh air to indoor and can filter the outdoor air if necessary. The dual airflow window can be used in all the climate regions.

Table 3

(a) Annual energy demand for heating by the apartment with the three types of windows

\begin{tabular}{|l|c|c|c|c|c|}
\hline \multirow{2}{*}{$\begin{array}{c}\text { Typical city } \\
\text { in each } \\
\text { climate zone }\end{array}$} & \multicolumn{3}{|c|}{ Heating demand (kWh) } & \multicolumn{2}{c|}{$\begin{array}{c}\text { Relative energy reduction } \\
\text { compared with the dual } \\
\text { airflow window (\%) }\end{array}$} \\
\cline { 2 - 6 } & Dual airflow & Blinds & Low-e & Blinds & Low-e \\
\hline Harbin 3253 & 4815 & 4424 & 48 & 36 \\
\hline Beijing 2630 & 3761 & 3525 & 43 & 34 \\
\hline Shanghai 1698 & 2394 & 2258 & 41 & 33 \\
\hline Guangzhou 843 & 1154 & 1105 & 37 & 31 \\
\hline Kunming 1512 & 1816 & 1753 & 21 & 16 \\
\hline
\end{tabular}

(b) Annual energy demand for cooling by the apartment with the three types of windows

\begin{tabular}{|l|c|c|c|c|c|}
\hline \multirow{2}{*}{$\begin{array}{c}\text { Typical city } \\
\text { in each } \\
\text { climate zone }\end{array}$} & \multicolumn{4}{|c|}{ Cooling demand (kWh) } & \multicolumn{2}{c|}{$\begin{array}{c}\text { Relative energy reduction } \\
\text { compared with the dual } \\
\text { airflow window (\%) }\end{array}$} \\
\cline { 2 - 6 } & Dual airflow & Blinds & Low-e & Blinds & Low-e \\
\hline Harbin 1356 & 1130 & 1492 & -16 & 11 \\
\hline Beijing 2421 & 1889 & 2735 & -22 & 13 \\
\hline Shanghai 3614 & 2497 & 4372 & -31 & 21 \\
\hline Guangzhou 5163 & 3884 & 5878 & -27 & 14 \\
\hline Kunming 321 & 266 & 379 & -17 & 18 \\
\hline
\end{tabular}

\section{Discussion}

The above results demonstrate that the dual airflow window can reduce significantly energy demand in heating season, but its heat recovery capacity in cooling season is limited. However, it does not mean that the dual airflow window should only be used in cold clim ate. This study assum ed that the dual window work ed in all the year round and it had no blinds or shades. The performance of the dual airflow window can be improved by only operating it when the tem perature differential between the two cavities is high and overhang shading devi ce and blinds could be added to the outside, inside or outer cavity of the window.

Note that a m ajor function of the dual airflow window is to supply fresh outdoor air to the apartment for improving indoor air quality. Energy demand may not be the only concern. The benefits of the window should ta ke the indoor air quali ty improvement into consideration. Although the other two windows can be opened for fres $h$ air, the fresh air is not stable and can cause severe draft in cold winter. 


\section{Conclusions}

This investigation developed a netw ork model for calcula ting the com plex heat transfer through the dual airflow window. The model could $\mathrm{c}$ onsider the heat transfer in the two cavities along the window height. The model has been succes sfully implemented into EnergyPlus, a building energy analysis program.

The network model implemented neglected the heat transfer in the third direction. The measured window surface tem peratures sh ow that the tem perature variation in the third direc tion w ere sm all com pare $\mathrm{w}$ ith that in the vertical and the cross sectio nal direction. Therefore, the heat transfer in the third direc tion is not important, although the airflow in the window was indeed three dimensional.

The two-dim ensional network $\mathrm{m}$ odel has been further validated by using the energy demand $\mathrm{m}$ easured from a test faci lity with the dual airflow window. The computed energy demand is nearly the s ame as the measured one. This indicates that the two-dimensional approx imations used in the dual airflow window are acceptable. Th e validated EnergyPlus program can be used to analyze energy in bu ildings with the dual airflow windows.

The validated EnergyPlus was then used to compare the annual energy demand of a small apartment of $60 \mathrm{~m}^{2}$ floor area with the dual airflow, low-e and blinds windows in five Chinese cities with different clim ates. The cities are Harbin (sev ere cold), Beijing (cold), Shanghai (hot in summ er and cold in winter), Guangzhou (hot in summer and mild in winter), and Kunming (mild). Without window ventilation, the energy dem and of the apartment with the three types of windows was sim ilar. The energy dem and of the apartment with the dual airflow window was $t$ he lowest for heating, and that with the blinds window was the lowest for cooling. When the window was assum ed to supply a total of $72 \mathrm{~m}^{3} / \mathrm{h}$ airflow to the apartm ent through th e windows, the trend of the energy demand looks sim ilar to that without vent ilation but the differences becom e very significant. Table 4 co ncludes that the apartm ent with the dual airflow windows could reduce the heating energy by $16-48 \%$ depending on the climate, compared with that with the other two types of windows. Howeve r, the cooling energy dem anded by the apartment with the dual airflow windows can be higher than that with the blinds windows because the later can effectively shade the solar radiation. When compared with the low-e windows, the cooling energy reduction of th e apartment with the dual airflow windows was only 11 to $21 \%$ because of low tem perature differential be tween the two flow streams in the window cavity.

From energy dem and point of view, the dual airflow window should be installed in buildings in cold clim ate. However, if improving air quality is a major consideration for a building, the window can be used in any climate. 
Table 4

Relative energy saving by the apartment with dual airflow windows

\begin{tabular}{|l|c|c|c|c|}
\hline \multirow{2}{*}{$\begin{array}{c}\text { Typical city in } \\
\text { each climate zone }\end{array}$} & \multicolumn{2}{|c|}{ Heating demand } & \multicolumn{2}{c|}{ Cooling demand } \\
\cline { 2 - 5 } & Blinds Low-e & Blinds & Low-e \\
\hline Harbin & 48 & 36 & -16 & 11 \\
\hline Beijing 43 & & 34 & -22 & 13 \\
\hline Shanghai 41 & & 33 & -31 & 21 \\
\hline Guangzhou 37 & & 31 & -27 & 14 \\
\hline Kunming 21 & & 16 & -17 & 18 \\
\hline
\end{tabular}

\section{Acknowledgements}

This work was partially supported by Shanghai Huobo Design Com pany and by the Ministry of Science and Technology of China through project "Research and Demonstration of Key Technologies for Build ing Energy Conservati on", the 11th FiveYear National Science and Technology Supporting Plan.

\section{References}

[1] J.M. Shen, Indoor air quality and health, Refrigerating Technology 1 (2007) 10-14.

[2] M.H. Sherm an, N. Matson, Residentia 1 ven tilation and en ergy characteristics, ASHRAE Transactions 103 (1) (1997) 717-730.

[3] Q.M. Luo, Impacts of ventilation strategies on IAQ, Refrigeration Air Conditioning \& Electric 2 (2007) 14-18.

[4] J.J. Li u, B. W ang, Y.H. Xu, R esearch on the energy saving perform ance of the enthalpy re covery ven tilator in $\mathrm{C}$ hinese re sidential buildings, Inte rnational Solar Energy Conference, Vol. 6, Denver, 2007, pp. 595-602.

[5] K. Zhong, Y.M. Kang, Applicab ility of a ir-to-air heat recovery ventilators in China, Applied Thermal Engineering, 29 (5-6) (2009) 830-840.

[6] D. Saelens, S. Roels, H. Hens, On the influence of the inlet tem perature in multipleskin facade modeling, E ighth Intern ational IBP SA Conf erence, Vol. 8, Eindhoven, Netherlands, 2003, pp. 11-14.

[7] D. Sael ens, S. Roe 1s, H. Hens, St rategies to im prove the energy perform ance of multiple-skin facades, Building and Environment, 43 (4) (2008) 638-650.

[8] P.H. Baker, M. McE voy, Test cell analys is of the use of a supply air window as a passive solar component, Solar Energy 69 (2) (2000) 113-130.

[9] J.R. Goss elin, Q. Chen, A com putational method for cal culating heat transfer and airflow through a dual-airflow window, Energy and Buildings 40 (2008) 452-458.

[10] J.R. Gosselin, Q. Chen, A dual-airflo w window for indoor air quality im provement and energy conservation in buildings, HVAC\&R Research 14 (3) (2008) 359-372.

[11] A. Werner, A. Roos, Simulations of coatings to avoid external condensation on low U-value windows, Optical Materials 30 (2008) 968-978.

[12] A. Tze mpelikos, The im pact of veneti an blind geom etry and tilt angle on view, direct light transmission and interior illuminance, Solar Energy 82 (12) (2008) 11721191. 
[13] R.K. Strand, D.B. Crawley, L.K. Lawrie, F.C. Winkelmann, W.F. Buhl, Y. J. Huang, D.E. Fisher, EnergyPlus : A new-generati on energy analy sis and load calculatio $n$ engine for building design, in: Proceedi ngs of the ACSA T echnology Conference on EnergyPlus, Cambridge, Massachusetts, 2000, pp. 1-12.

[14] A. Yezioro, B. Dong, F. Leite, A n applied artif icial in telligence approach tow ards assessing building performance simulation tools, Energy and Buildings 40 (4) (2008) 612-620.

[15] R.K. Strand, C.O. Pedersen, Implementation of a radiant heating and cooling $\mathrm{m}$ odel into an integrated bu ilding energy analys is pro gram, A SHRAE Transaction s 103 (1997) 949-958. 